\title{
JUDGMENT BASED ON AGREEMENT OF THE PARTIES IN CROATIAN LAW: A CRITICAL ANALYSIS FROM THE COMPARATIVE LEGAL PERSPECTIVE****
}

Summary: $\quad$ This paper considers judgments based on agreement of the parties in Croatian law, more precisely particular aspects of this consensual form which previous studies have assessed to be potentially problematic. These aspects include the objectives of reaching agreement, the gravity of criminal offences subject to agreement, the role of the court, and the legal position of the defence and that of the victim. These aspects are analysed primarily from a comparative-law perspective, since the Croatian version of plea bargaining, just like specific models adopted in some other European countries, was inspired by the same American model. Besides American law, the research includes Italian, French, Swiss, German and Austrian law. The goal of the comparative research is to find out whether the Croatian model contains some specific features which perhaps differ from positive comparative European legal solutions, but also result in theoretical and practical problems. The study will also include analysis of the jurisprudence of the Supreme Court of the Republic of Croatia concerning primarily the issue of judicial control over the agreement of the parties, which has been most disputed in domestic literature and in judicial practice.

Keywords: judgment based on agreement of the parties, consensual justice, consensual procedures, plea bargaining, criminal procedure, judicial control

\footnotetext{
* $\quad$ Elizabeta Ivičević Karas, PhD, Full Professor, Faculty of Law, University of Zagreb, Trg Republike Hrvatske 14, 10000 Zagreb Republic of Croatia. E-mail address: elizabeta.ivicevic@pravo.hr. ORCID: https://orcid.org/0000-0001-5279-3709.

** Ante Novokmet, PhD, Associate Professor, Faculty of Law, Josip Juraj Strossmayer University of Osijek, S. Radića 13, 31000 Osijek, Republic of Croatia. E-mail address: ante.novokmet@pravos.hr. ORCID: https://orcid.org/0000-0001-8833-9751.

*** Igor Martinović, PhD, Associate Professor, Faculty of Law, University of Rijeka, Hahlić 6, 51000 Rijeka, Republic of Croatia. E-mail address: imartinovic@pravri.hr. ORCID: https://orcid.org/0000-0002-7648-2443.

**** This work has been fully supported by the Croatian Science Foundation under the project "Systematic approach to models of negotiated justice in Croatian criminal procedure" (IP-2019-04-1275).
} 


\section{INTRODUCTION}

Judgment based on agreement of the parties is a Croatian model of plea bargaining, a consensual procedure which exists in various forms in a number of comparative legal systems. Although a relatively new procedural form, it was quickly accepted in Croatian judicial practice primarily due to the fact that it enables the economical and speedy solving of criminal cases. ${ }^{1}$ This paper does not offer a comprehensive analysis of judgments based on agreement of the parties in Croatian law, which has relatively often been discussed in the domestic literature. Instead, this paper is devoted to particular aspects of this consensual form which have been detected in previous studies as potentially problematic and which include the objectives of reaching agreement, the gravity of criminal offences subject to agreement, the role of the court, as well as the legal position of the defence and also that of the victim. ${ }^{2}$ These aspects will be analysed primarily from a comparative-law perspective, since the Croatian version of plea bargaining, just like specific models adopted in some other European countries, was inspired by the same American model. ${ }^{3}$

Versions of plea agreements in continental European countries differ in many respects from the American model, and also differ from each other, primarily due to the countries' different legal traditions and various basic principles of domestic criminal procedures. The research will therefore include, besides American law, Italian, French, Swiss, German and Austrian law. These European legal systems are close to the Croatian system due to historical bonds, geographical proximity or/and traditional influence. The goal of the comparative research is to find out whether the Croatian model contains some specific features which perhaps differ from positive comparative European legal solutions, but which also result in theoretical and practical problems. The research will also include analysis of the jurisprudence of the Supreme Court of the Republic of Croatia primarily concerning the issue of judicial control over the agreement of the parties, which has, at least up to this moment, been most disputed in domestic literature and in judicial practice.

\section{COMPARATIVE LEGAL ANALYSIS}

\subsection{AMERICAN MODEL OF PLEA BARGAINING - AN INSPIRATION FOR EUROPEAN LEGAL LEGISLATORS}

Settlements in criminal proceedings are one of the most significant features of the US judicial system. Although plea agreement has been applied in the United States for more than two

1 See Turudić, I., Pavelin Borzić, T., Bujas, I., Sporazum stranaka u kaznenom postupku - trgovina pravdom ili? Pravni vjesnik, Vol. 32, No. 1, 2016, p. 122. See also Tomičić, Z., Novokmet, A., Nagodbe stranaka u kaznenom postupku - dostignuća i perspektive, Pravni vjesnik, Vol. 28, No. 3-4, 2012, pp. 177 - 178.

2 See Ivičević Karas, E., Consensual Justice in Croatian Criminal Procedural Law: the Need for a Systematic Approach, in "EU 2020 Lessons from the Past and Solutions for the Future, EU and Comparative Law Issues and Challenges Series (ECLIC) - ISSUE 4, University of Josip Juraj Strossmayer Faculty of Law, Osijek, 2020, p. 429.

3 Krstulović Relija, A., Primjena kazne na zahtjev stranaka kao mehanizam konsenzualnog stranačkog upravljanja postupkom u talijanskom kaznenom procesnom pravu, Hrvatski ljetopis za kazneno pravo i praksu, Vol. 9, No. 2, 2002, pp. 374 - 380. 
hundred years, ${ }^{4}$ putting this into everyday practice began only in 1970 after the US Supreme Court, in the famous case of Brady v. United States, ${ }^{5}$ gave legitimacy to consensual procedures for agreements, emphasising on that occasion that this was an integral part of the US criminal justice system, significantly contributing to the efficiency of criminal justice. ${ }^{6}$ Today, plea bargaining has virtually become almost the only way of dealing with criminal cases. According to statistical indicators, in 2019, as many as $97 \%$ of cases ended in a settlement. ${ }^{7}$

Although the term settlement is usually denoted in everyday speech by the phrase plea bargaining, it should be emphasised that there are several forms of plea agreements. In particular, the Federal Rules of Criminal Procedure (hereinafter: FRCP) ${ }^{8}$ distinguish between charge bargaining and sentence bargaining (Art. 11 (c) (1) FRCP) as two basic forms of settlement, while in practice count bargaining and fact bargaining are also mentioned as types of plea agreement. ${ }^{9}$ Charge bargaining is the most common and widespread form of plea bargaining. It is an agreement between the prosecutor and the defendant in which the prosecutor agrees to mitigate the indictment in exchange for the defendant's confession by giving up the original charge for a lesser charge (for example, the prosecutor may propose dropping the murder count for the defendant and have him plead guilty to manslaughter). ${ }^{10}$ Count bargaining is a subtype of charge bargaining that comes to the fore when a person is charged with multiple crimes. ${ }^{11}$ In such a situation, the prosecutor and the defendant may enter into an agreement that the defendant will plead guilty to certain charges in exchange for other charges being dropped. Fact bargaining is also a subtype of charge bargaining by which the prosecutor and the defendant agree on certain facts of the offence for which the defendant will plead guilty but which do not correspond to the offence actually committed. In other words, the defendant will plead guilty in order to keep certain facts out of the case that would lead to a harsher punishment..$^{12}$ Finally, sentence bargaining is an agreement by which the prosecutor and the defendant agree on a particular punishment to be imposed on the defendant on condition that he pleads guilty (Art. 11 (c), 1, B, C, FRCP). However, it should be emphasised that the prosecutor does not impose a punishment, but the parties bring their agreement before the court, according to which the judge can refuse this kind of agreement if he or she disagrees with the punishment that has been offered by the prosecutor. Simply because of this risk, sentence bargaining is rarely used in practice, since charge bargaining is a safer and easier way for an agreement that will satisfy both the prosecutor and the defendant. ${ }^{13}$

4 See: Fischer, G., Plea Bargaining's Triumph, The Yale Law Journal, Vol. 109, 2000, pp. 857-1086, Alschuler, A. W., Plea Bargaining and Its History, Law \& Society Review, Vol. 13, No. 2, 1979, pp. 211-245.

5 Brady v. United States, 397 U.S. 742, 90 S. Ct. 1463 (1970).

6 Kavanaugh, J., Plea Bargaining: The Prosecutor's Perspective, Police Law Quarterly, vol. 6, no. 4, 1977, pp. 6-7.

72019 Annual report and sourcebook of federal sentencing statistics https://www.ussc.gov/sites/default/files/pdf/research-andpublications/annual-reports-and-sourcebooks/2019/2019-Annual-Report-and-Sourcebook.pdf, p. 56. Accessed 1 November 2020.

8 https://www.law.cornell.edu/rules/frcrmp. Accessed 1 November 2020.

9 See: Parker, J. F., Plea Bargaining, American Journal of Criminal Law, Vol. 1, No. 2, 1972, p. 188.

$10 \quad$ Ibid.

11 Ibid., p. 191.

12 Ibid.

13 Ibid., p. 189. 
The mentioned various forms of settlements were able to develop and can exist successfully today in the US due to the very specific features of that legal system. One feature is the adversarial nature of criminal proceedings where the position of the judge is extremely passive, and the key initiative in gathering evidence is placed on both the prosecutor and the defendant, which is why it is a purely party-driven procedure. ${ }^{14}$ Investigation conducted by the police and the prosecutor is one-sided and exclusively focused on gathering procedural material to establish the defendant's guilt, while the defendant and his counsel undertake their investigation to gather evidence in favour of the defence. ${ }^{15}$ These are essentially two parallel investigations, each focused on its own goal. One aims at establishing the guilt of the defendant, and the other at establishing the defendant's innocence. ${ }^{16}$ In such a situation, neither party is aware of the opposing party's evidence until the preliminary hearing aimed at disclosing evidence between the parties, in order to allow the court and the parties to question the legality of the evidence gathered during the investigation. In such a constellation of relations between the parties, the prosecutor and the defendant, using their procedural rights, directly influence the course and outcome of the criminal proceedings. ${ }^{17}$ Another feature is directly related to the position and powers of the prosecutor in criminal proceedings. The prosecutor's conduct is characterised by wide discretionary powers. ${ }^{18}$ Discretion is manifested to the extent that the prosecutor decides entirely independently on whether to prosecute a person before the court, for which criminal offence, and under which law, or simply to drop the charges. ${ }^{19}$ In doing so, the prosecutor's decision is not subject to judicial review, and, as each prosecutor's office is decentralised and there is no strict hierarchy, then the prosecutor's decisions are not subject to review by higher prosecutors and he or she is not required to follow any instructions in the respective work. ${ }^{20}$ It follows that the prosecutor is the master of the pre-trial criminal proceedings, which implies broad authority to autonomously decide when and for which criminal offence to offer the defendant settlement depending on the quality of evidence available at a given moment..$^{21}$ Such broad discretionary authority gives the prosecutor legal power and the flexibility to negotiate, even in cases where he or she does not have solid evidence of the defendant's guilt.

As much as settlements appear to be an effective and simple system of conducting criminal justice, today they have been severely criticised in scientific and professional circles. ${ }^{22}$ One of the main problems is that settlement sacrifices justice, as a result of which a significant

14 Viano, E. C., Plea Bargaining in the United States: A Perversion of Justice, Revue internationale de droit pénal, Vol. 83, No. 1-2, 2012, p. 111.

15 Damaška, M., O nekim učincima stranački oblikovanog pripremnog kaznenog postupka, Hrvatski ljetopis za kazneno pravo i praksu, Vol. 14, No. 1, 2007, pp. 3-13.

16 Tomičić, Novokmet, op. cit. note 1, p. 153.

17 Viano, op. cit. note 14.

18 See: Albonetti, C. A., Prosecutorial Discretion: The Effects of Uncertainty, Law \& Society Review, Vol. 21, No. 2, 1987, pp. $291-314$. Alschluer, A. W., The Prosecutor's Role in Plea Bargaining, The University of Chicago Law Review, Vol. 36, No. 1, 1968, pp. 50-112.

19 Lafave, W. R., The Prosecutor's Discretion in The United States, The American Journal of Comparative Law, Vol. 18, No. 3, 1970, pp. 538-539.

20 Pizzi, W. T., Understanding Prosecutorial Discretion in the United States: The Limits of Comparative Criminal Procedure as an Instrument of Reform, Ohio State Law Journal, Vol. 54, No. 5, p. 1049-1050.

21 Bibas, S., Plea Bargaining outside the Shadow of Trial, Harvard Law Review, Vol. 117, No. 8, 2004, pp. 2470-2476. 
proportion of criminals are not punished harshly enough. ${ }^{23}$ Furthermore, many defendants prefer to accept the prosecutor's generous offer and enter into a settlement to avoid the risk of a harsh punishment before the jury. However, a peculiar problem is the frequent criticism that plea agreement is the result of coercion conducted under the direction of the prosecutor. ${ }^{24}$ Primarily driven by interest in obtaining as many convictions as possible, prosecutors abuse their powerful discretion to obtain the defendant's confession at all costs, even in cases where they do not have solid evidence that the person has committed a crime. In such situations, prosecutors often add multiple charges or they charge the defendant with a more serious offence to induce the defendant to plead guilty during the negotiations and agree to a conviction for a lighter criminal offence. Finally, most defendants do not have the funds to pay for a lawyer. Therefore, they have the fate of receiving legal aid from a public defender who does not have enough financial and time resources to provide quality legal aid, so they regularly advise the defendant to plead guilty with minimum investigation. ${ }^{25}$

\subsection{DIFFERENT MODELS OF PLEA BARGAINING IN EUROPEAN CONTINENTAL LEGAL SYSTEMS}

\subsubsection{Italian model of patteggiamento}

Application della pena su richiesta delle parti - patteggiamento (Art. $444-448 \mathrm{CPP}^{26}$ ) is a model of plea agreement developed in Italian law as an alternative, more economical procedure to the main hearing. ${ }^{27}$ This consensual form implies that the defendant agrees not to challenge the accusation, and in return the punishment is reduced by up to a third.

The traditional form of this agreement (patteggiamento tradizionale) may be required for criminal offences punishable by imprisonment for a term not exceeding two years (also when a fine is included), while the extended plea agreement (patteggiamento allargato) allows the parties to agree on a sanction which, reduced by up to one third, does not exceed five years of custodial sentence alone or together with a fine. ${ }^{28}$ Thereby, the law (in Art. 444(1-bis) explicitly excludes from bargaining specific types of criminal offences, such as organised crime, terrorism, child prostitution, child pornography, group sexual violence, human trafficking, kidnapping for the purpose of extortion, etc., as well as defendants who have been declared habitual, professional, or repeat offenders, or those with a tendency to commit offences. In relation to individual criminal offences, the possibility of agreement is conditioned by the return of the entire acquired profit or material gain from the criminal offence (Art. 444(1-ter) CPP).

23 Berdejó, C., Criminalizing Race: Racial Disparities in Plea Bargaining, Boston College Law Review, Vol. 59, No. 4, 2018, pp. 11871249.

24 McCoy, C., Plea Bargaining as Coercion: The Trial Penalty and Plea Bargaining Reform, Criminal Law Quarterly, Vol. 50, No. 1 \& 2, 2005, pp. 67-107.

25 Walker Wilson, M. J., Defense Attorney Bias and the Rush to the Plea, Kansas Law Review, Vol. 65, No. 2, pp. 271-325.

26 Codice di procedura penale, Aggiornato al D.L. 17 marzo 2020, n. 18, https://www.altalex.com/documents/codicialtalex/2014/10/30/codice-di-procedura-penale. Accessed 5 December 2020.

27 Weichbrodt, K., Das Konsensprinzip strafprozessualer Absprachen, Duncker \& Humblot, Berlin, 2006, p. 252. 
The request may be presented by either of the parties to the judge, at the preliminary hearing, or until the opening of the trial in cases of specific procedures (Art. 446 (1) CPP). The role of a judge is to verify whether the specific criminal offence can be the subject of agreement, the correctness of the legal qualification of the offence, as well as the adequacy of the proposed punishment, i.e. whether the proposed punishment may fulfil the purpose of sanctioning (Art. 444(2) CPP). This means that the parties may not negotiate on the legal qualification of the offence. In addition, the court controls not only whether the formal preconditions are met, but also the material preconditions, so that it can acquit the defendant, and also reject the request if it considers the requested sentence inappropriate, given all the circumstances of the case and the purpose of punishment. ${ }^{29}$ Although the stated power of the court is not explicitly prescribed in the provisions regulating patteggiamento, it derives from Art. 27 of the Italian Constitution, to which the Italian Constitutional Court also referred when it declared unconstitutional the provisions of Art. 444 para. 2 of the CPP because the judge could not assess the conformity of the sentence imposed by the parties and reject their request in the case of its unfavourable assessment. ${ }^{30}$ The Constitutional Court emphasised that it is the duty of the court to assess the appropriateness of the sentence in each case given the special preventive purpose that it must accomplish. ${ }^{31}$ If an agreement is permitted in this regard, the judge may not impose a type or measure of punishment other than that specified in the agreement. The judge may order the defendant to appear if he or she deems it appropriate to verify the voluntary nature of the request or consent (Art. 446(5) CPP).

The parties may challenge the agreement before the court of cassation, but only for reasons related to the will of the defendant, the lack of correlation between the request and the sentence imposed, the incorrect legal qualification of the act, or an unlawful sentence or security measure (Art. 448(2-bis) CPP).

The procedure of patteggiamento, including passing a judgment, is not public. In addition, it is completely closed to victims, meaning that the victim does not have any possibility to influence the contents of the draft sentence, which may be prepared even without his or her knowledge, nor does the victim have the possibility to argue his or her disagreement. ${ }^{32}$ Moreover, the victim does not have the opportunity to actively participate in the criminal proceedings in the capacity of the injured party (parte civile), since, in the patteggiamento procedure, the judge does not make a decision on a claim for indemnification. ${ }^{33}$ On one hand, if we look from the perspective of fundamental rights, such legislation is not in itself contrary to Convention law, as long as the victim can exercise his or her civil rights in litigation. ${ }^{34}$ Yet, such a marginalised role of the victim is criticised in literature from the aspect of European legal standards guaranteed by Directive 2012/29/UE, which should enable the victim to actively participate in criminal proceedings, advocate for his or her interests, and influence the outcome. ${ }^{35}$

\footnotetext{
29 Krstulović, op. cit. note 3, pp. 378 and 388. See also Tomičić, Novokmet, op. cit. note 1, pp. 175 and 177.

30 Corte Costituzionale, sentenza 2 luglio 1990, n. 313 (Gazzetta ufficiale, 1 serie speciale, 4 luglio 1990, n. 27).

31 Ibid.

32 Sanna, A., Il "patteggiamento" tra prassi e novelle legislative, Wolters Kluwer CEDAM, 2018, p. 45.

33 Ibid., pp. $45-46$.

34 See ECtHR, Mihova v. Italy, Décision sur la recevabilité, 25000/07, 30 March 2010. See Simonato, M., Deposizione della vittima e giustizia penale, Wolters Kluwer CEDAM, 2014, pp. 52 - 53. 
In conclusion, in Italian law, plea bargaining is allowed only for less serious criminal offences. The parties may not negotiate on the legal qualification of the offence. The court controls not only the formal preconditions, but also the material preconditions, in the sense that it can acquit the defendant, or reject the request if it considers the requested sentence inappropriate. The procedure before the court is not open to the public, or to the victim.

\subsubsection{French model of plaider coupable}

The French model of plea bargaining - comparution sur reconnaissance préalable de culpabilité (plaider coupable) was introduced with the legislative reform of 2004 and was directly inspired by the American original. ${ }^{36}$ It is regulated in Art. 495-7 - 495-16 CPP. ${ }^{37}$

This form of consensual procedure may be applied to all offences from the category of délits, which includes offences punishable with imprisonment of up to ten years, ${ }^{38}$ with the exception of minors (persons under the age of eighteen) and matters of press offences, manslaughter and political offences (Art. 495-16 CPP), as well as offences of wilful and unintentional attacks on the integrity of persons and sexual assault when perpetrators are punished with a term of imprisonment of more than five years (Art. 495-7 CPA). The prosecutor may propose one or more of the main or additional penalties, and when a prison sentence is proposed, it cannot exceed one year, or half of the prison sentence incurred (Art. 495-8 CPA). The legal qualificaiton is not an object of the agreement.

The presence of the defence counsel is mandatory during the admission of the facts, and the defendant has the right to consult freely with the defence counsel before making his or her decision (Art. 495-8 CPA). The role of the lawyer is not only to counsel the defendant, but also to advise him or her. ${ }^{39}$

Once the proposed sentence is accepted in the mandatory presence of the defence counsel, the public prosecutor files a request for homologation before the court. The judge must first hear the defendant and his or her lawyer, and then verify "the reality of the facts and their legal qualification" (Art. 495-9 CPP). Only after that may the judge, in a reasoned order, decide to approve the punishments proposed by the public prosecutor. The procedure is open to the public (Art. 495-9 CPP) and is therefore transparent. The order must be motivated by the findings that the person recognises the facts of which he or she is accused, and accepts the proposed sentence, but also that the sentence is "justified in view of the circumstances of the offence and the personality of its author" (Art. 495-11 CPP). This means that the judge has the opportunity to take into account a whole range of objective and subjective circumstances relevant for assessing the appropriateness of the proposed sentence.

The judgment may be appealed by both parties for all the reasons prescribed in Art. 498, 500, 502 and 505 CPP (Art. 495-11 CPP). On one hand, the relatively wide possibility of ap-

\footnotetext{
36 Papadopoulos, I., « Plaider coupable » La pratique américaine. Le texte français, PUF, 2004, p. 71.

37 Code de procedure penale, Version en vigueur au 08 décembre 2020, https://www.legifrance.gouv.fr/codes/texte_lc/ LEGITEXT000006071154/. Accessed 6 December 2020.

38 Hamdan, S., Absprachen im französischen Strafuerfahren? Nomos, 2018, p. 29.

39 Ibid., p. 91.
} 
peal can be called into question because this version of plea agreement implies a decision based on the agreement of the parties, and, in this sense, it has a contractual character. However, on the other hand, it provides for an additional guarantee against any error of fact or of interpretation of the will of the person in the course of the homologation procedure before the court..$^{40}$ In addition, the defendant may apply to the Court of Cassation in accordance with the general rules. ${ }^{41}$

The victim is also informed of the procedure, invited to appear before the court, may become a civil party, and may seek compensation of damage. The victim may also appeal against the order if he or she was not present at the hearing when the order was issued (Art. 495-13 $\mathrm{CPP}$ ). Besides being able to use specific procedural rights, the victim has the right to participate in the public hearing which also contributes to the transparency of the whole procedure as a whole.

If the proposed sentence is not accepted by the party or by the judge, the report on the proceedings of plaider coupable may not be sent to the competent court, nor may the parties refer to it (485-14 CPP). In this way, the continued procedure will not be contaminated by the contents of the unsuccessful agreement, which could be harmful to the defence.

In conclusion, in French law, plea bargaining is allowed only for less serious to more serious offences. The parties may not negotiate on the legal qualification of the offence. The court controls not only the legal qualification, but also whether the requested sentence is "justified in view of the circumstances of the offence and the personality of its author". The hearing is open to the public and to the victim. Finally, there are rather large possibilities of appeal.

\subsubsection{Swiss model of abgekürztes Verfahren}

The accelerated procedure (abgekürztes Verfahren) is the closest relative of plea bargaining in the Swiss criminal procedure. At the national level, it was introduced in legislation in 2011, when the first Swiss Criminal Procedure Code ${ }^{42}(\mathrm{CPC})$ came into force. ${ }^{43}$ The main purpose of this consensual form is to accelerate criminal proceedings and ultimately relieve the judiciary. ${ }^{44}$ The rules governing the accelerated procedure are laid down in Articles $358-362$ CPC.

The initiative to conduct accelerated proceedings is always in the hands of the defendant (Art. 385-1 CPC), i.e. the public prosecutor may not initiate it ex officio. The defendant may request these proceedings provided he or she admits the facts which are essential to the legal assessment of the case (den Sachverhalt, der für die rechtliche Würdigung wesentlich ist) and recognises, at least in principle, the civil claims. From the start of this accelerated procedure, the

\footnotetext{
40 Papadopulos, op. cit. note 36, p. 90.

41 Hamdan, op. cit. note 38, pp. $93-94$.

42 Code de procédure pénale, du 5 octobre 2007 (Etat le 1er février 2020), https://www.droit-bilingue.ch/rs/lex/2005/23/20052319unique-en-fr.html. Accessed 7 December 2020.

43 The majority of jurisprudence was unfavourable to the introduction of plea bargaining, e.g. Donatsch, Vereinbarungen im Strafprozess, in: Festschrift zum 50jährigen Bestehen der Schweizerischen Kriminalistischen Gesellschaft, Bern, 1992, p. 159; Hauser, Schweri, Schweizerisches Strafprozessrecht, Basel/Frankfurt, 1999., § 49 . 
defendant must be assisted by a defence counsel. ${ }^{45}$ The most important legislative constraint in initiating the accelerated procedure is the provision which limits it to cases in which the public prosecutor requests a custodial sentence of not more than five years (Art. 358-2 CPC), which means that ordinary proceedings must be conducted if the prosecutor seeks a harsher sentence. But even if the prosecutor seeks a more lenient sentence, he or she is not obliged to accept the defendant's request to conduct an accelerated procedure. His decision on whether to conduct an accelerated procedure is final and does not need to contain a statement of reasons (Art. 395-1 CPC). In any case, the defendant's request and the prosecutor's decision thereupon must be made prior to the bringing of charges.

If the public prosecutor decides to conduct accelerated proceedings, he or she serves the indictment on the parties, which contains, apart from its standard elements required by the Criminal Procedure Code, some special elements, most importantly the sentence (das Strafmass) (Art. 360-1 CPC). Within ten days, the parties must irrevocably declare whether or not they consent to the indictment, whereby "the party" is not only the accused, but also the private claimant (Privatklägerschaft), i.e. a person suffering harm (die geschädigte Person) who expressly declares that he or she wishes to participate in the criminal proceedings. If the private claimant fails to reject the indictment in writing within the time limit, he or she is considered to have agreed to it (Art. 360-3 CPC). If the indictment is rejected by any of the parties, an ordinary preliminary procedure (ordentliches Vorverfahren) will be conducted.

When the parties (the accused and the private claimant) approve the indictment, the public prosecutor submits the indictment with the case file to the court of first instance, which conducts a main hearing (Hauptverhandlung) (Art. 361-1 CPC). The main hearing is remarkably swifter than in ordinary proceedings as no procedure for taking evidence is to be conducted. After questioning the defendant, the court establishes if the defendant admits the facts on which the charges are based and if this admission corresponds to the circumstances laid out in the case file. Such a summary hearing is, however, not just a formality: it is still a public hearing, which ensures that the agreement between the parties does not escape public scrutiny and responsibility.

Upon the closure of the main hearing, the court is not obliged to issue a judgement. It freely decides (befindet frei darüber) if the conduct of the accelerated procedure is lawful and appropriate (rechtmässig und angebracht), if the charge corresponds to the outcome of the main hearing and to the case file and if the requested sanctions are adequate (angemessen) (Art. 362-1 (PC). If the requirements for a judgment in the accelerated procedure are not met, the court returns the case file to the public prosecutor in order to conduct ordinary preliminary proceedings. This decision may not be contested. Statements made by the parties with regard to the accelerated procedure may not be used in any subsequent ordinary procedure.

On the other hand, if the court - upon its free deliberation - finds that the requirements for a judgment in the accelerated proceedings are met, it issues a judgment that sets out the offences, sanctions and civil claims contained in the indictment, which means that the court may not unilaterally modify the agreement between the parties once it decides to accept it (Art. 362-2 CPC). The court is not obliged to give an exhaustive statement of the grounds for 
the judgment; it only summarily declares that the requirements for the accelerated proceedings have been met.

As regards the right to appeal against the judgment in the accelerated proceedings, this legal remedy may be filed only if the party does not accept the indictment, i.e. if the judgment was delivered in the absence of a formal agreement, ${ }^{46}$ or if the judgment does not correspond to the indictment (Art. 362-5 CPP).

Accelerated proceedings in Swiss legal systems can certainly be said to constitute a form of plea bargaining, but they are nevertheless marked by general principles of the Swiss criminal procedure, especially by the inquisitorial principle (Amtsermittlungsgrundsatz), ${ }^{47}$ i.e. by the active role played by the judge who is not only authorised, but also obliged, to investigate ex officio (without a proposal of the person concerned) the facts on which a decision is to be based. Having this in mind, it should not be surprising that the court retains an important role in accelerated proceedings in deciding if the plea agreement is to be accepted or rejected. Another significant mechanism of control is the right of the victim not only to participate in the simplified procedure in the capacity of a complaining party ${ }^{48}$ but also to discontinue the plea bargaining. The procedure is open to the public and is therefore transparent. Finally, an important mechanism of control is operated through the fact that plea bargaining is restricted to minor and moderate criminal offences.

\subsubsection{German plea agreement "Absprache"}

Implementation of consensual justice in German criminal proceedings has been gradually evolving since the 1970s. ${ }^{49}$ Firstly, under pressure from a large number of cases, the German judiciary gradually relativised the principle of compulsory prosecution in favour of the principle of opportunity by accepting the conditional waiver of criminal prosecution, and then, through the institution of a penal order, sought to expedite proceedings by skipping the hearing as the central stage of the criminal proceedings. ${ }^{50}$ At the same time, kinds of negotiations and agreements outside the court (Absprache) began to take place. ${ }^{51}$ The essence of the negotiations lay in the fact that the defendant pleaded guilty, and that the judge in turn promised a more lenient penalty than would have been given at the hearing. Informal settlements have gradually gained so much momentum that they have become regular in the practice of judicial bodies. Despite such developments, the legislator remained passive until 2009, when settlements were finally enacted by the Act on the Regulation of Agreements in Criminal Proceedings of 28 May 2009. ${ }^{52}$

\footnotetext{
46 Ibid., p. 2305.

47 Ibid., p. 2271.

48 Ibid., p. 2273.

49 Herrman, J., Bargaining Justice - A Bargain for German Criminal Justice? University of Pittsburgh Law Review, Vol. 53, No. 3, 1992, p. 755.

Weigend, T., Iontcheva Turner, J., The Constitutionality of Negotiated Criminal Judgments in Germany, German Law Journal, p. 83-84.

51 Iontcheva Turner, J., Judicial Participation in Plea Negotiations: A Comparative View, American Journal of Comparative Law, Vol. 54, No. 1, 2006, p. 217.

See Gesetz zur Regelung der Verständigung im Strafverfahren, July 29, 2009, BUNDESGESETZBLATT, Teil I, [BGBL. I].
} 
The implementation of consensual procedures is most often explained by the need to increase the efficiency of proceedings and to reduce their costs ${ }^{53}$ thorough party-driven proceedings. Nevertheless, even after enacting settlement, Germany remained consistent with the tradition of its criminal procedure based on the standpoint that its primary task is to find the substantive truth. ${ }^{54}$ This is clear from $\S 257$ c (1) of the StPO, which stipulates that the court may reach an agreement with the parties on the further course and outcome of the proceedings, but the outcome of such an agreement must in no way jeopardise the court's general obligation to establish the truth and the ex officio taking of evidence of all facts and means of proof which are relevant to the decision ( $§ 244$ (2) StPO). Thus, the establishment of substantive truth has remained the fundamental premise of German criminal proceedings, from which it follows that any confession of the defendant based on agreement must be checked for accuracy by the taking of evidence during the main hearing. It follows from the above that a judgment under an agreement can be rendered by a court only when the offence has been fully investigated and there are grounds to believe that the admission of guilt is genuine. ${ }^{55}$ This was confirmed by the Federal Constitutional Court, emphasising that settlement alone is not sufficient for the pronouncement of a judgment, but the court must base the judgment on a sufficiently founded conviction determined by facts and circumstances reached through the entire main trial. ${ }^{56}$ In addition to the principle of substantive truth, another important principle of German criminal justice is the so-called principle of guilt (Schuldprinzip). As in the regular procedure, so in the procedure of concluding a settlement, the court has the duty to find the facts necessary to establish the level of the defendant's guilt. ${ }^{57}$ In other words, the court is obliged to determine the right measure of punishment taking into account the proportional correlation between the offender's blameworthiness and the sanction imposed on him. ${ }^{58}$

The court has a central role in the plea agreement. Not only does the court, in suitable cases, ${ }^{59}$ initiate the plea agreement procedure but it proposes a lower minimum and an upper maximum sentence that can be imposed on the defendant after the settlement has been made ( 257c (3) StPO). The moment at which it is possible to start negotiations is determined very broadly. For each stage of the procedure, the StPO explicitly envisages the possibility of discussing the state of the proceedings with the parties to the proceedings. Thus, before filing an indictment, the prosecutor may discuss the state of the proceedings with the participants in the proceedings ( $\left(160 \mathrm{~b}\right.$ StPO) ${ }^{60}$ The court may also initiate plea negotiations during the judicial review of the indictment ( $\$ 202 \mathrm{StPO})$, and the law allows it to do so during the prepa-

53 Ivičević Karas, op. cit. note 2, p. 416.

54 See: Hettinger, M., Die Absprache im Strafverfahren als rechtsstaatliches Problem, JuristenZeitung, Vol. 66, No. 6, 2011, pp. 292301.

55 Rauxloh, R. E., Formalization of Plea Bargaining in Germany: Will the New Legislation Be Able to Square the Circle? Fordham International Law Journal, Vol. 34, No. 2, 2011, p. 321.

56 Mosbacher, A., The Decision of the Federal Constitutional Court of 19 March 2013 on Plea Agreements, German Law Journal, Vol. 15, No. 1, p.7

57 Weigend, Iontcheva Turner, op. cit. note 50, p. 85

58 Ibid.

59 The term "in suitable cases" is very broad and vague, but it is suggested that the plea agreement should be taken into account in all cases in which it will significantly speed up the procedure. Murmann, U., Reform oder Wiederkehr? - Die gesetzliche Regelung der Absprachen im Strafverfahren, Zeitschrift für Internationale Strafrechtsdogmatik, No. 10, 2009, p. 534.

6o The literature indicates that it is questionable whether the prosecutor and the defendant can create binding agreements without the involvement of the court. Rauxloh, op. cit. note 55 . 
rations for the trial after the indictment has been confirmed ( $\$ 212$ StPO). Particularly significant is $\S 257 \mathrm{~b}$ StPO, allowing plea negotiations to be initiated even during the main hearing if the court deems it useful for the faster conclusion of the proceedings. However, regardless of whether the negotiations started before or during the trial, the law explicitly provides the obligation to adduce before a court at the hearing all negotiations conducted before or during the trial with the obligation to record the course, content and outcome of a negotiated agreement ( $\$ 273$ (1) StPO). If no agreement was negotiated, this will also be noted in the record ( $\$ 273$ (1a) StPO). This ensures that the negotiation procedure as well as the concluded settlement are transparent and objectively verifiable through a potential appeal procedure.

The court is in principle bound by the negotiated agreement as well as by the initial proposal of the sanction. However, the court will cease to be bound by a negotiated agreement if legally or factually relevant circumstances have been overlooked or have arisen and the court is therefore then convinced that the prospective sentencing range is no longer appropriate to the severity of the offence or the degree of guilt. The same applies if the defendant's further conduct in the proceedings does not correspond to that on which the court's prediction was based ( $\$ 257$ (4) StPO). In such circumstances, the court is obliged to inform the parties without delay and the defendant's confession may not be used in such cases ( $₹ 257 c$ (4) StPO) ${ }^{61}$ Due to the legal consequences that arise for the defendant from this situation, the court is obliged to explicitly instruct the defendant about the conditions for and consequences of the court deviating from the prospective outcome of the negotiated agreement ( $\$ 257$ (5) StPO). The possibility for the court to withdraw from the agreement opens the door to legal uncertainty. Here, the question arises as to how to justify the possibility for the court to suddenly disregard a confession that concurs with other evidence in the case file just because new aggravating facts have emerged that go beyond the initial indication of a maximum sentence. In such a case, it implies that the agreement fails and the legal fiction is assumed that the court is no longer bound by the draft agreement, as well as that the defendant did not give a confession. However, a judge will find it difficult to maintain objectivity and impartiality if he or she has previously created the preconception of the defendant's guilt on the basis of a confession and other evidence in the file. It is therefore questionable whether, in the further course of the proceedings, the judge can completely disregard the earlier confession given and ensure that the proceedings are conducted in a manner in which the presumption of innocence of the defendant is consistently respected.

The defendant's waiver of the right to appeal cannot be a subject of the agreement. Thus, in $\S 302$ (1) of the StPO it is expressly prescribed if a negotiated agreement has preceded the judgment, a waiver will be precluded. As an additional safeguard, § 35a (3) of the StPO explicitly provides for an additional instruction on the right to legal remedy (qualified instruction): "where a negotiated agreement has preceded a judgment, the person concerned shall also be informed that he is in any case free in his decision to seek an appellate remedy". In this way, an attempt was made to prevent a waiver of the right to appeal from becoming a subject of agreement and thus to exclude the agreement between the parties from any control of the appellate court. However, insisting on the defendant's right to appeal even in the case where the judgment is

61 Some scholars criticise such a solution and point out that the preconditions for giving up from the legally binding function of the agreement are so vague that the defendant's confidence in the effectiveness of the agreement and all his or her efforts can easily be betrayed. Beulke, W., Strafprozessrecht, C.F. Müller Verlag, Heidelberg, 2010, p. 253. 
based on a settlement has advantages and disadvantages. The positive side of the right to appeal is reflected in the fact that the court must pay equal attention when writing the reasoning of the judgment based on the settlement, since the control of the legality and merits of the agreement before the appellate court is then ensured. The second question is how motivated the court will be to make a concession to the defendant and offer a settlement when it is aware of the possibility that a higher court may overturn this decision acting on the legal remedy, which has negative connotations for the judge's career appraisals. ${ }^{62}$ Therefore, there is a real danger that the parties to the settlement will, behind closed doors, informally agree on the terms of the agreement in order to avoid disruption of the mutual trust-based working relationship which could potentially threaten future negotiations. ${ }^{63}$

\subsubsection{Absence of plea agreements in Austrian law}

In Austria, there is no statutory regulation to explicitly forbid negotiations between the state prosecutor and the defendant, but there is no regulation to allow it, either. In other words, there is no mention of plea bargaining in Austrian statutory law. A distant relative of plea bargaining would be the so-called diversion (Rücktritt von der Verfolgung - Diversion, §§ 198-209b Criminal Procedure Code), which is a unilateral offer by the state prosecutor who may decide to close proceedings conditionally if the offender is ready to pay a fine, do community service (gemeinnützige Leistungen) or agree on compensation with the victim (Tatausgleich). As the condition to proceed with diversion is willingness on the part of the defendant, the idea of diversion certainly does have something is common with plea bargaining, but it is still very distinct from classic plea bargaining, which involves the guilty plea of the defendant in return for some concession from the prosecutor. In the case of diversion, the defendant does not plead guilty when accepting diversion nor does the court deliver a judgment as a result of the diversion procedure.

The fact that Austrian statutory law does not allow or explicitly forbid negotiations between the state prosecutor (or the court) and the defendant has prompted the question whether informal, "off the record" negotiations are permissible at all and whether the outcome of such negotiations (if they are to be considered permissible) is binding on the prosecutor and the court. This issue has been dealt with by the Supreme Court of Austria. ${ }^{64}$ In this case, a defence lawyer discussed the case with the judge who was the president of the competent court chamber at the Higher Regional Court Graz. After the judge agreed to impose a relatively lenient sentence if the defendant pleads guilty, the lawyer advised his client to accept this informal offer. However, the court chamber did not uphold the "promise" of its president and imposed a harsher penalty in spite of the guilty plea. The Supreme Court dismissed the defendant's appeal (Nichtigkeitsbeschwerde) while also using this case as an occasion to make some remarks about negotiations in general. The opinion of the highest Austrian court is unambiguous: it found negotiations between the defendant and the judge, except for those held in accordance with diversion proceedings, to be in "blatant contradiction" with the basic principles of the

\footnotetext{
62 Ibid.

63 Ibid.

64 OGH 11 Os $77 / 4$.
} 
Austrian law of criminal procedure, namely with the duty of the court to establish substantive truth (Erforschung der materiellen Wahreheit), which cannot be accomplished if the court "contracts with the (alleged) offender". As pointed out by the Supreme Court, the parties of such negotiations could even be subject to disciplinary and criminal prosecution.

To conclude, Austria retains the traditional civil law approach to criminal justice, which considers the establishment of truth as the sine qua non of proper adjudication and sentencing. Therefore, the court is not perceived as an impartial referee, but as an active subject whose duty is to investigate the facts of the case in order to establish the truth and properly apply the law. This conception has been marginally eroded by the desire to make procedures more efficient, which has resulted in the creation of a few legislatively amended "shortcuts", e.g. diversion and the mandate procedure, where all such exceptions must be expressly prescribed by law. Informal negotiations would undermine this system and are therefore still frowned upon by the judiciary. ${ }^{65}$ Even though Austrian law, for the stated reasons, cannot be analysed here in this comparative research, it still provides valuable information on a system which operates without its own version of a plea-bargaining procedure. This is particularly relevant if we know that Croatian criminal procedural law has traditionally been influenced by the Austrian one.

\section{ANALYSIS OF SPECIFIC ASPECTS OF JUDGMENT BASED ON AGREEMENT OF THE PARTIES IN CROATIAN LAW}

\subsection{THE OBJECTIVES OF THIS CONSENSUAL FORM AND THE SCOPE OF CRIMINAL OFFENCES}

Judgment based on agreement of the parties was introduced in Croatian legislation with the new Criminal Procedure Act (CPA) in $2008,{ }^{66}$ primarily with the goal of providing an economical and fast resolution of criminal cases. ${ }^{67}$ The corresponding consensual form that existed in the previous CPA of $1997^{68}$ was reserved for less serious to more serious criminal offences, punishable with imprisonment of up to ten years. When enacting the new Criminal Procedure Act in 2008, the Croatian legislator drastically widened the scope of application of judgment based on agreement of the parties to all criminal offences, ${ }^{69}$ including the most serious ones and those under the jurisdiction of the Office for the Suppression of Corruption and Organised Crime. Probably for that reason, the specific purpose of the traditional form of plea

65 Jurisprudence is not unanimous on the matter: some authors are in favour of legislative amendments to enable plea bargaining (e.g. Ruhri, Verständigungen im Strafverfahren. Betrachtungen de lege ferenda Anwaltsblatt 2010, p. 243) while others are against (e.g. Böckemühl, Kier, Verständigungen in Strafverfahren - Ein Plädoyer gegen die Kodifizierung einer "StPO light" in Österreich, Anwaltsblatt 2010, p. 402).

66 Criminal Procedure Act, Official Gazette 152/08, 76/09, 80/11, 121/11, 91/12, 143/12, 56/13, 145/13, 152/14, 70/17, 126/19, $126 / 19$.

67 See note 1.

68 Criminal Procedure Act, Official Gazette 110/97, 27/98, 58/99, 112/99, 58/02, 143/02, (62/03), 178/04, 115/06.

69 Ivičević Karas, E., Trial Waiver Systems in Croatia, Towards a Rights-based Approach to Trial Waiver Systems, LEAP, 2019, pp. 8 - 9., accessible at: https://www.fairtrials.org/sites/default/files/publication_pdf/20190513_Trial_Waivers_Croatia_Final.pdf. Accessed 4 December 2020. 
bargaining was supplemented with another one - obtaining witness testimony against the defendant's co-defendant, which testimony, once the defendant becomes a convicted person, would be given in another criminal procedure. Obtaining witness testimony is a typical motivation for consensual forms applied in organised crime cases, such as the crown witness or witness immunity. ${ }^{70}$ Although this specific purpose of bargaining is not explicitly prescribed by law, it is suggested in the "Instructions of the State Attorney General on proceedings during bargaining", ${ }^{71}$ and it is used in Croatian practice. ${ }^{72}$ The question now is whether the traditional model of plea bargaining may offer all the safeguards that are implemented in another consensual form which exists in Croatian law - the crown witness. Unlike the crown witness, whose status is granted by the court under strict conditions, including providing a complete and true statement and withdrawal of the status in the case of failure to do so, judgment based on agreement of the parties does not contain any such safeguards. This means that there is no guarantee that the defendant will testify truthfully once the court delivers a judgment based on agreement of the parties.

On the other hand, this comparative research has shown that, as far as concerns comparative consensual forms corresponding to judgment based on agreement of the parties, the main objective of reaching an agreement is to achieve procedural efficiency, speed and economy. An additional purpose could also be the humanisation of proceedings for less serious criminal offences that should not necessarily entail holding a public trial. ${ }^{73}$ Accordingly, all compared European legislations that regulate their own specific forms of plea bargaining, with the exception of Germany (which may be excluded from the comparative perspective on this question due to the very specific role of German courts in the accelerated procedure), provide this consensual form for less serious or more serious criminal offences, and explicitly or implicitly exclude criminal offences of organised crime and corruption, as well as other serious criminal offences. Accordingly, as these consensual forms are not used for more serious criminal offences, they do not serve for the specific purpose of obtaining witness testimony against future defendants who were formerly co-defendants, a purpose that is typical with regard to organised crime, as already pointed out.

It can be concluded that the regulation of Croatian judgment based on agreement of the parties differs significantly from similar European consensual forms with respect to the gravity of the criminal offences concerned, and with respect to its very specific purpose - obtaining a witness testimony. This suggests that both the scope of criminal offences that may be subject to judgment based on agreement of the parties should be reconsidered, as well as the specific purpose of this consensual form in Croatian law.

$70 \quad$ Ivičević Karas, op. cit. note 2, pp. $414-416$.

71 Instructions of the State Attorney General on proceedings during bargaining with the suspect/defendant on terms of pleading guilty and the punishment state that the bargaining allows "the detection of other offences or other offenders". Naputak o pregovaranju i sporazumijevanju s okrivljenikom o priznanju krivnje i sankciji, O-2/09, od 17. veljače 2010., p. 3, http://www. dorh.hr/PresudaPoSporazumu. Accessed 10 December 2020.

72 Ivičević Karas, op. cit. note 2, pp. 417 - 419; Ivičević Karas, op. cit note 69, p. 12. See an example in the jurisprudence of the Supreme Court, VSRH, II-4 Kr 61/2020-4 of 4 September 2020.

73 See Krapac, D., Presuda na zahtjev stranaka u stadiju istrage u hrvatskom kaznenom postupku, in: Decennium Moztanicense (ed. Pavišić, B.), Rijeka, 2008, p. 138. 


\subsection{POWERS OF THE COURT}

The issue of judicial control over consensual procedures, and particularly over judgment based on agreement of the parties, has been one of the most disputed issues ever since this consensual form was introduced with the new CPA of $2008 .^{74}$ The reason for this may lie in the fact that the new version of plea bargaining, judgment based on agreement of the parties, which replaced the old one, significantly reduced the powers of the court to control the parties' agreement. ${ }^{75}$ At the same time, as stated above, the legislation expanded the scope of application of this consensual form to the most serious criminal offences and therewith increased the stakes for all involved or interested in the outcome of bargaining: the prosecutor, the defendant, the victim, but also the public. Therefore, the powers of the court to question the parties' agreement are an issue of upmost importance.

In Croatian criminal procedure, judgment based on agreement of the parties may be delivered either before the indictment panel or at the preparatory hearing for the main trial before the president of the trial panel. Parties can only negotiate the terms of a guilty plea and an agreement on a sentence, and not the legal qualification of the offence (Art. 360(1) CPA). Even though any of the parties may initiate negotiations, which are conducted in camera, a written statement on the agreement, with specific content (Art. 360 (4) CPA) must be submitted to the court. Then the panel must first determine that the parties agree with the content of the submitted statement, and then decide on the indictment (Art. 361(1) CPA). If the indictment is confirmed, the panel will decide on accepting the statement (Art. 361(2) CPA). The panel may refuse to accept the statement for two reasons (Art. 361(3) CPA): firstly, if the acceptance of the statement is not in accordance with the sentencing prescribed by law, or, secondly, if the agreement is not otherwise lawful. Although this provision could provide relatively large possibilities for the court to control the statement, the jurisprudence of the Supreme Court of the Republic of Croatia gave a different interpretation. ${ }^{76}$ In one case, deciding on the request for the protection of legality, filed by the State Attorney General, the Supreme Court, in reference to Art. 361(3) CPA, stated that if the interpretation of the first instance court were accepted "that the cited legal expression allows the court to assess the agreed punishment in accordance with the provision of Art. 47 CC / 11 and that, depending on such assessment, does not accept or does accept the statement, and thus the agreed penalty, this would lead to inequality and arbitrariness in the proceedings of the first instance court both in the case when the statement is accepted and for that reason refused". ${ }^{77}$ It added that "the court is not at all aware of the circumstances that the parties had in mind when agreeing on such a sentence, because the law does not oblige them to state them in the statement, and the court itself, given the stage of the proceedings (preparatory hearing), has no legal possibilities to determine those circumstances, and it is self-evident that circumstanc-

74 See Ivičević Karas, E., Puljić, D., Presuda na temelju sporazuma stranaka u hrvatskom kaznenom procesnom pravu i praksi Županijskog suda u Zagrebu, Hrvatski ljetopis za kazneno pravo i praksu, Vol. 20, No. 2, 2013, pp. 841 - 842; Tomičić, Novokmet, op. cit. note 1, pp. 182 - 184.; Turudić, Pavelin Borzić, Bujas, op. cit. note 1, pp. 143 - 147.; Ivičević Karas, op. cit. note 69, pp. 9 - 11.; Ivičević Karas, op. cit. note 2, pp. $423-424$. investigating judge not to accept the parties' request not only if there were no legal conditions for it, but also if the collected evidence (in the case file) did not justify the delivery of a consensual judgment. Krapac, op. cit. note 73, pp. 144. 
es which are not known cannot even be judged" ${ }^{78}$ Deciding on the request, the Supreme Court quashed the final decision of the county court and remanded the case for a new decision. Yet, the county court made the same decision once again, so the Supreme Court, deciding on another request for the protection of legality, reversed the final decision of the county court, accepted the statement for rendering a judgment based on agreement of the parties and finally rendered a judgment. ${ }^{79}$ The same reasoning was upheld in another case, when the Supreme Court, deciding on the request for the protection of legality, quashed the final decision of the county court and remanded the case for a new decision. ${ }^{80}$ In this manner, potentially great possibilities for the court to assess the adequacy of the parties' agreement on the basis of the cited legal provision, especially with regard to the proposed punishment or other criminal law measure, have been reduced to a minimum.

Furthermore, if the court accepts the statement (on the agreement), the judgment may impose only the punishment or other measure as specified by the parties in the statement. ${ }^{81}$ Imposing another punishment or criminal law measure would constitute a substantive violation of criminal procedure provisions which would lead to the quashing of the judgment and a retrial. ${ }^{82}$ It would be the same if the court deviated from the defendant's statement on the claim for indemnification, which is an integral part of the agreement. ${ }^{83}$ Yet, the fact that the court may not intervene in the proposed sanction may actually be understood as an argument in favour of granting the court more powers to question the agreement from different aspects, and particularly regarding the punishment.

Finally, judicial control of the agreement is particularly important if we bear in mind that the possibilities to appeal the judgment based on agreement of the parties are rather limited. In the Croatian criminal procedure, parties may not challenge the judgment for an erroneous decision on a punishment or other criminal law measure, or for an erroneously or incompletely established factual situation, unless the defendant found out about the evidence of exclusion of unlawfulness and guilt only after the judgment was delivered (Art. 364 CPA).

Looking from the comparative perspective, unlike Italian, French, Swiss and particularly German law, Croatian law provides for very limited possibilities for the court to reject the agreement of the parties. In German law, the court not only controls the agreement, but it is directly involved in negotiations and reaching an agreement between the parties. This, though, opens additional questions which will not be discussed here. ${ }^{84}$ On the other hand, in Italian, French and Swiss law, the court may reject the agreement not only for its unlawfulness, but also if the proposed punishment does not correspond to the purpose of the punishment as proclaimed in the criminal code, and this is always in the case of less serious and more

\footnotetext{
78 Ibid.

79 VSRH, Kzz 17/2018-5 of 8 and 9 May 2018.

80 VSRH, Kzz 2/2018-3 of 24 January 2018. In this case, however, the president of the panel gave a separate opinion in which he explained the reasons why he voted to reject the request for the protection of legality.

81 See VSRH, I Kž 411/12-6 of 27 August 2013 and 11 March 2014.

82 In one case, the judgment based on agreement of the parties was not rendered on the initial statement on the agreement which was signed by the defendant, but on another statement which was signed only by the defence counsel and it contained a harsher punishment that the one the defendant actually agreed on with the state attorney. VSRH, I Kž-Us 134/14-6 of 13 January 2015. 
serious criminal offences. If we take one more look at the Croatian solution, it is clear that the legislative text would actually allow a similar interpretation. Yet, the jurisprudence of the Supreme Court, as we have seen, has not allowed it. Now, the solution in force, on one hand, provides agreements for the most serious criminal offences, while, on the other hand, the role of the court is dramatically reduced to the minimum. All the deficiencies that may appear in the agreed punishment, which are feared to be more obvious and radical the more serious the criminal offence in question is, now cannot be remedied through substantive and effective control of the court. It may therefore be concluded that the Croatian legislator should reconsider the role of the court in providing judicial control over this consensual form.

\subsection{PROCEDURAL AND DEFENCE RIGHTS}

Issues concerning procedural and defence rights during plea bargaining are numerous, complex and difficult. Most of them concern consensual justice in general. This research has no pretentions to analyse all of them in detail. Instead, it will focus on several specific points.

According to Croatian law, for the entire negotiation with the state attorney, the defendant must be assisted by a defence counsel (Art. 360 CPA). The defence counsel is one of the signatories of the statement on the agreement submitted to the court. The defendant may initiate the negotiations with the state attorney, but the state attorney is not obliged to engage in the negotiations. Therefore, there is no obligation of the state attorney that would actually be complementary to the defendant's right to agree on the punishment and other criminal law measures, a right which is actually proclaimed in Art. 64(1)11 CPA. ${ }^{85}$ Looking from the comparative legal perspective, the possibility to bargain on the punishment and to reach an agreement is a possibility, not a defence right.

As concerns mandatory defence, this is explicitly prescribed in French and Swiss law. It may be justified by the fact that the defendant will not only plead guilty, but also waive a number of guarantees of a fair trial applicable to the full extent only at the trial stage. The defence counsel should compensate for this waiver at least to a certain extent. In addition, the defendant should be advised with regard to the negotiated punishment. In Croatian law, the role of the defence counsel is particularly important if we know that the court questions the agreement only to a very limited extent. Besides this role of procedural assistant to the defendant, the defence counsel has a broader role in guaranteeing that the negotiation and agreement process will be lawful. If the defence counsel has been present, the defendant's subsequent allegations of unlawful conduct in the negotiations and agreement procedure will therefore be less credible. ${ }^{86}$

Another defence rights issue concerns situations where an agreement cannot be reached, or where it is not accepted by the court. If the parties withdraw the statement for a judgment to be delivered based on their agreement, the statement and all other data related to it must

85 See Ivičević Karas, op. cit. note 2, pp. 426 - 427.

86 The Supreme Court in such cases always verifies whether the defence counsel was present throughout the bargaining process and before the court. See, for example, the judgment of the Supreme Court VSRH, I Kž-Us 103/2019-4 of 4 September 2019. See also decision VSRH, I Kž-Us 109/15-4 of 29 September 2015. 
be excluded from the case file and delivered to the investigating judge (Art. 362 (2) CPA). This includes the proposal for negotiation and all submissions related to that negotiation, so that the court at later stages of the process (at the trial and appeal) would not be "infected" with the content of the negotiations. ${ }^{87}$ The fact that the defendant was willing to negotiate, and that he or she actually engaged in those negotiations, should not be to the defendant's detriment. The same procedure should be applied if the court does not accept the statement on the reached agreement.

\subsection{VICTIMS' RIGHTS AND PUBLIC INTEREST}

Victims' rights and public interest may be considered together, as will be explained. As concerns the victim, in Croatian law he or she is not included in the negotiations between the parties on the agreement. Only once the parties reach agreement does the state attorney inform the victim or the injured party (Art. 365(5) CPA). An exception is prescribed for criminal offences against life and limb and against sexual liberties, for which a punishment of more than five years' imprisonment is prescribed by law, and for which the state attorney must obtain the victim's consent for the negotiation (Art. 360(6) CPA). If the victim is deceased or is incapable of consent, the state attorney should refer to a close relative of the victim.

As concerns all victims, they are not included in the negotiation process, which takes place, as stated, in camera. Once the parties reach an agreement and it is brought to the court, the indictment panel decides on the indictment at a hearing which is closed to the public. The injured party or the victim is not summoned.

From a comparative perspective, it can be noticed that victims have rather different legal positions in different legal systems. In French and Swiss law, victims have the right to participate in the procedure before the court and the procedure is public. In Switzerland, victims can even prevent the parties reaching an agreement. On the other hand, in Italian law, the hearing in the patteggiamento procedure is closed to the victims, just as it is closed to the public. Hence, at least at first sight, the position of the victim in Croatian law might seem similar to the one in Italy. Yet, there are important differences. In Italian law, the parties may reach an agreement, patteggiamento, only for less serious and for some more serious offences. In addition, the court has the power to control not only the lawfulness of the agreement, but also the adequacy of the punishment proposed, so the lack of the victim's contribution, as well as the absence of the public, may be compensated for at least to a certain extent through the role of the court. On the other hand, the absence of victims and the absence of the public when the court delivers a judgment based on agreement of the parties in Croatian law is combined with the very limited power of the court to question the agreement, and all the more so in cases which may concern even the most serious criminal offences.

To conclude, opening a judgment based on agreement of the parties to the public, and allowing the victim at least to be heard, should be among the first steps in any future legislative initiative in this field. As has already been stated, returning power to the court to question 
agreements and limiting the scope of this consensual form should certainly be considered within the same initiative.

\section{CONCLUSION}

This comparative legal study has shown that the regulation of Croatian judgments based on agreement of the parties differs significantly from similar European consensual forms in many aspects. One of them concerns the gravity of the criminal offences that may be subject to bargaining, and another is the very specific purpose of this consensual form - obtaining witness testimony. In Croatian law, plea bargaining is allowed even for the most serious criminal offences, and for the purpose of obtaining witness testimony in another criminal procedure.

As concerns the role of the court in bringing a judgment based on agreement of the parties, looking from the comparative point of view, it should be concluded that Croatian law provides for very limited possibilities for the court not to accept an agreement of the parties. The legislative text could, though, be interpreted in a manner that would allow the court to question the parties' agreement not only for the reason of its unlawfulness, but also to question whether the proposed punishment would correspond to the purpose of punishment. Yet, the jurisprudence of the Supreme Court has not allowed this. This means that the legislative solution in force allows, on one hand, agreements for the most serious criminal offences while, on the other hand, the role of the court is dramatically reduced to the minimum. All the deficiencies that may appear in the agreed punishment, which can be expected to be more obvious and radical the more serious the criminal offence in question is, cannot be remedied without substantive and effective control of the court. This suggests that the Croatian legislator, in its future initiatives, should enable the court to exercise complete judicial control over this consensual form.

As regards the defendant, his or her position is indeed reinforced through mandatory defence. Yet, compared to other analysed legal systems, the role of the defence counsel is particularly important in the Croatian version of plea bargaining if we bear in mind the limited power of the court to question the agreement and the alleged lack of power to intervene for reason of the inadequate punishment proposed, even in cases of the most serious criminal offences.

Finally, opening to the public a hearing where the court decides on the agreement of the parties and delivers a judgment based on that agreement, as well as allowing the victim to be at least heard, is among the first steps to be taken in any future legislative initiative in this field. The presence of victims, and particularly the presence of the public when the court renders a judgment of conviction, contributes to the transparency of criminal proceedings which should be the legislator's priority in any democratic society founded on the rule of law. 


\section{REFERENCES}

1. Albonetti, C. A., Prosecutorial Discretion: The Effects of Uncertainty, Law \& Society Review, Vol. 21, No. 2, 1987, pp. 291-314.

2. Alschluer, A. W., The Prosecutor's Role in Plea Bargaining, The University of Chicago Law Review, Vol. 36, No. 1, 1968, pp. 50-112.

3. Alschuler, A. W., Plea Bargaining and Its History, Law \& Society Review, Vol. 13, No. 2, 1979, pp. 211-245.

4. Berdejó, C., Criminalizing Race: Racial Disparities in Plea Bargaining, Boston College Law Review, Vol. 59, No. 4, 2018, pp. 1187-1249.

5. Beulke, W., Strafprozessrecht, C.F. Müller Verlag, Heidelberg, 2010.

6. Bibas, S., Plea Bargaining outside the Shadow of Trial, Harvard Law Review, Vol. 117, No. 8, 2004, pp. 2464-2547.

7. Böckemühl, Kier, Verständigungen in Strafverfahren - Ein Plädoyer gegen die Kodifizierung einer „StPO light" in Österreich, Anwaltsblatt 2010.

8. Code de procédure pénale suisse, Commentaire Romand (Jeanneret, Y. ; Kuhn, A. ; Perrier Depeursinge, C. eds.), Helbing Lichtenhahn, 2019.

9. Damaška, M., O nekim učincima stranački oblikovanog pripremnog kaznenog postupka, Hrvatski ljetopis za kazneno pravo i praksu, Vol. 14, No. 1, 2007, pp. 3-14.

10. Donatsch, Vereinbarungen im Strafprozess, in: Festschrift zum 50jährigen Bestehen der Schweizerischen Kriminalistischen Gesellschaft, Bern, 1992, pp. 159 - 177.

11. Fischer, G., Plea Bargaining's Triumph, The Yale Law Journal, Vol. 109, 2000, pp. 857-1086.

12. Hamdan, S., Absprachen im französischen Strafuerfahren?, Nomos, 2018.

13. Hauser, Schweri, Schweizerisches Strafprozessrecht, Basel/Frankfurt, 1999.

14. Herrman, J., Bargaining Justice - A Bargain for German Criminal Justice?, University of Pittsburgh Law Review, vol. 53, no. 3, 1992, pp. 755-776.

15. Hettinger, M., Die Absprache im Strafverfahren als rechtsstaatliches Problem, JuristenZeitung, Vol. 66, No. 6, 2011, pp. 292-301.

16. Iontcheva Turner, J., Judicial Participation in Plea Negotiations: A Comparative View, American Journal of Comparative Law, Vol. 54, No. 1, 2006, pp. 199-267.

17. Ivičević Karas, E., Consensual Justice in Croatian Criminal Procedural Law: the Need for a Systematic Approach, in „EU 2020 - Lessons from the Past and Solutions for the Future, EU and Comparative Law Issues and Challenges Series (ECLIC) - ISSUE 4, University of Josip Juraj Strossmayer Faculty of Law, Osijek, 2020, pp. $405-432$.

18. Ivičević Karas, E., Puljić, D., Presuda na temelju sporazuma stranaka u hrvatskom kaznenom procesnom pravu i praksi Županijskog suda u Zagrebu, Hrvatski ljetopis za kazneno pravo i praksu, Vol. 20, No. 2, 2013, pp. $823-849$.

19. Johnson, T., Public Perceptions of Plea Bargaining, American Journal of Criminal Law, Vol. 46, No. 1, 2019, pp. 133-156.

20. Kavanaugh, J., Plea Bargaining: The Prosecutor's Perspective, Police Law Quarterly, Vol. 6, No. 4, 1977, pp. 5-25.

21. Krapac, D., Presuda na zahtjev stranaka u stadiju istrage u hrvatskom kaznenom postupku, in: Decennium Moztanicense (ed. Pavišić, B.), Rijeka, 2008, pp. 137 - 150. 
22. Krstulović Relija, A., Primjena kazne na zahtjev stranaka kao mehanizam konsenzualnog stranačkog upravljanja postupkom u talijanskom kaznenom procesnom pravu, Hrvatski ljetopis za kazneno pravo i praksu, Vol. 9, No. 2, 2002, pp. 373 - 399.

23. Lafave, W. R., The Prosecutor's Discretion in The United States, The American Journal of Comparative Law, Vol. 18, No. 3, 1970, pp. 532-548.

24. McCoy, C., Plea Bargaining as Coercion: The Trial Penalty and Plea Bargaining Reform, Criminal Law Quarterly, Vol. 50, No. 1 \& 2, 2005, pp. 67-107.

25. Mosbacher, A., The Decision of the Federal Constitutional Court of 19 March 2013 on Plea Agreements, German Law Journal, Vol. 15, No. 1, pp. 5-14.

26. Murmann, U., Reform oder Wiederkehr? - Die gesetzliche Regelung der Absprachen im Strafverfahren, Zeitschrift für Internationale Strafrechtsdogmatik, No. 10, 2009, pp. 526-538.

27. Papadopoulos, I., « Plaider coupable » La pratique américaine Le texte français, PUF, 2004.

28. Parker, J. F., Plea Bargaining, American Journal of Criminal Law, Vol. 1, No. 2, 1972, pp.187-209

29. Pizzi, W. T., Understanding Prosecutorial Discretion in the United States: The Limits of Comparative Criminal Procedure as an Instrument of Reform, Ohio State Law Journal, Vol. 54, No. 5, pp. 1325-1373.

30. Rauxloh, R. E., Formalization of Plea Bargaining in Germany: Will the New Legislation Be Able to Square the Circle?, Fordham International Law Journal, Vol. 34, No. 2, 2011, pp. 296-331.

31. Sanna, A., Il "patteggiamento" tra prassi e novelle legislative, Wolters Kluwer CEDAM, 2018.

32. Simonato, M., Deposizione della vittima e giustizia penale, Wolters Kluwer CEDAM, 2014.

33. Tomičić, Z., Novokmet, A., Nagodbe stranaka u kaznenom postupku - dostignuća i perspektive, Pravni vjesnik, Vol. 28, No. 3-4, 2012, pp. 149 - 190.

34. Turudić, I., Pavelin Borzić, T., Bujas, I., Sporazum stranaka u kaznenom postupku - trgovina pravdom ili? Pravni vjesnik, Vol. 32, No. 1, 2016, pp. 121 - 153.

35. Viano, E. C., Plea Bargaining in the United States: A Perversion of Justice, Revue internationale de droit pénal, Vol. 83, No. 1-2, 2012, pp. 109-145.

36. Walker Wilson, M. J., Defense Attorney Bias and the Rush to the Plea, Kansas Law Review, Vol. 65, No. 2, pp. 271-325.

37. Weichbrodt, K., Das Konsensprinzip strafprozessualer Absprachen, Duncker \& Humblot, Berlin, 2006.

38. Weigend, T., Iontcheva Turner, J., The Constitutionality of Negotiated Criminal Judgments in Germany, German Law Journal, Vol. 15, No. 1, pp. 81-105.

\section{LIST OF REGULATIONS AND ACTS}

1. Code de procédure pénale, du 5 octobre 2007 (Etat le 1er février 2020), https://www.droit-bilingue. ch/rs/lex/2005/23/20052319-unique-en-fr.html. Accessed 7 December 2020.

2. Code de procedure penale, Version en vigueur au 08 décembre 2020, https://www.legifrance.gouv. fr/codes/texte_lc/LEGITEXT000006071154/. Accessed 6 December 2020.

3. Codice di procedura penale, Aggiornato al D.L. 17 marzo 2020, n. 18, accessible at: https://www. altalex.com/documents/codici-altalex/2014/10/30/codice-di-procedura-penale. Accessed 5 December 2020.

4. Criminal Procedure Act, Official Gazette 110/97, 27/98, 58/99, 112/99, 58/02, 143/02, (62/03), 178/04, 115/06. 
5. Criminal Procedure Act, Official Gazette 152/08, 76/09, 80/11, 121/11, 91/12, 143/12, 56/13, 145/13, 152/14, 70/17, 126/19, 126/19.

6. Gesetz zur Regelung der Verständigung im Strafverfahren, July 29, 2009, BUNDESGESETZBLATT, Teil I, [BGBL. I].

7. Naputak o pregovaranju i sporazumijevanju s okrivljenikom o priznanju krivnje i sankciji, O-2/09, od 17. veljače 2010., p. 3, http://www.dorh.hr/PresudaPoSporazumu.Accessed 10 December 2020.

\section{DECISIONS OF THE SUPREME COURT OF THE REPUBLIC OF CROATIA}

1. VSRH, I Kž-Us 60/12-4 of 10 October 2012.

2. VSRH, I Kž 411/12-6 of 27 August 2013 and 11 March 2014.

3. VSRH, I Kž-Us 134/14-6 of 13 January 2015.

4. VSRH, I Kž-Us 109/15-4 of 29 September 2015.

5. VSRH, Kzz 38/16-3 of 27 September 2017.

6. VSRH, Kzz 2/2018-3 of 24 January 2018.

7. VSRH, Kzz 17/2018-5 of 8 and 9 May 2018.

8. VSRH, I Kž-Us 103/2019-4 of 4 September 2019.

9. VSRH, I Kž 545/2019-4 of 30 October 2019.

10. VSRH, II-4 Kr 61/2020-4 of 4 September 2020.

\section{WEBSITE REFERENCES}

1. 2019 Annual report and sourcebook of federal sentencing statistics https://www.ussc.gov/sites/ default/files/pdf/research-and-publications/annual-reports-and-sourcebooks/2019/2019-Annual-Report-and-Sourcebook.pdf, p. 56. Accessed 1 November 2020.

2. https://www.law.cornell.edu/rules/frcrmp. Accessed 1 November 2020.

3. Ivičević Karas, E., Trial Waiver Systems in Croatia, Towards a Rights-based Approach to Trial Waiver Systems, LEAP, 2019, pp. 8 - 9, accessible at: https://www.fairtrials.org/sites/default/files/publication_pdf/20190513_Trial_Waivers_Croatia_Final.pdf. Accessed 4 December 2020.

4. Patteggiamento, https://www.treccani.it/enciclopedia/patteggiamento/. Accessed 5 December 2020. 


\section{PRESUDA NA TEMELJU SPORAZUMA STRANAKA U HRVATSKOM PRAVU: KRITIČKA ANALIZA IZ POREDBENOPRAVNE PERSPEKTIVE}

\section{Sažetak}

U ovome se radu razmatra presuda na temelju sporazuma stranaka u hrvatskom pravu, odnosno pojedini aspekti ovog sporazumnog oblika koji su u nekim prethodno provedenim istraživanjima istaknuti kao potencijalno problematični. Ti aspekti uključuju ciljeve postizanja sporazuma, težinu kaznenih djela koja su predmet sporazuma, ulogu suda, pravni položaj obrane te pravni položaj žrtve. Navedeni aspekti analiziraju se prvenstveno iz poredbenopravne perspektive, budući da su hrvatska inačica sporazuma o priznanju krivnje (plea-bargaining) i pojedini specifični oblici ovog sporazuma usvojeni u nekim drugim europskim zemljama nadahnuti istim američkim modelom. Uz američko pravo, istraživanje obuhvaća talijansko, francusko, švicarsko, njemačko i austrijsko pravo. Cilj poredbenog istraživanja jest utvrditi ima li hrvatski model ovog konsenzualnog oblika neka specifična obilježja koja se možda razlikuju od europskih poredbenopravnih rješenja te uzrokuju li upravo ta specifična obilježja teorijske i praktične probleme. Istraživanje je obuhvatilo i analizu prakse Vrhovnog suda Republike Hrvatske koja se prvenstveno odnosi na pitanje sudske kontrole sporazuma stranaka, a ta je problematika dosad izazvala najviše rasprave i u domaćoj literaturi, i u sudskoj praksi.

Ključne riječi: $\quad$ presuda na temelju sporazuma stranaka, konsenzualna pravda, konsenzualni postupci, sporazum o priznanju krivnje, kazneni postupak, sudska kontrola

\section{(c) (1) (8)}

This work is licensed under a Creative Commons

Attribution-NonCommercial 4.0 International License.

\footnotetext{
* Dr. sc. Elizabeta Ivičević Karas, redovita profesorica Pravnog fakulteta Sveučilišta u Zagrebu, Trg Republike Hrvatske 14, 10000 Zagreb. E-adresa: elizabeta.ivicevic@pravo.hr. ORCID: https://orcid.org/0000-0001-5279-3709.

** Dr. sc. Ante Novokmet, izvanredni profesor Pravnog fakulteta Sveučilišta Josipa Jurja Strossmayera u Osijeku, S. Radića 13, 31000 Osijek. E-adresa: ante.novokmet@pravos.hr. ORCID: https://orcid.org/0000-0001-8833-9751.

*** Dr. sc. Igor Martinović, izvanredni profesor Pravnog fakulteta Sveučilišta u Rijeci, Hahlić 6, 51000 Rijeka. E-adresa: imartinovic@ pravri.hr. ORCID: https://orcid.org/0000-0002-7648-2443.
} 